\title{
HUBUNGAN KONSENTRASI KLOROFIL-A DAN SUHU PERMUKAAN LAUT DENGAN HASIL TANGKAPAN IKAN PELAGIS UTAMA DI PERAIRAN LAUT JAWA DARI CITRA SATELIT MODIS
}

\section{(RELATIONSHIP CHLOROPHYLL-A CONCENTRATION AND SEA SURFACE TEMPERATURE WITH PRIMARY PELAGIC FISH CATHES IN JAVA SEA FROM MODIS SATELLITE IMAGES)}

\author{
Ega Putra ${ }^{2}$, Jonson Lumban Gaol ${ }^{2}$, Vincentius P. Siregar ${ }^{1,2}$ \\ ${ }^{1}$ Corresponding author \\ 2 Departemen Ilmu dan Teknologi Kelautan \\ Fakultas Perikanan dan Ilmu Kelautan, Institut Pertanian Bogor \\ E-mail: vincents@biotrop.org
}

\begin{abstract}
This research aims to study spatial and temporal variation of chlorophyll-a concentration and sea surface temperature as well as his relationship with pelagic fish catches in Java Sea. The results showed in $2006^{\text {th }}-2010^{\text {th }}$ sea surface temperaturerice occurs by $1^{\circ} \mathrm{C}$ which monthly average range between $27,9^{\circ} \mathrm{C}-31,4^{\circ} \mathrm{C}$. Sea surface temperature are relatively higher in transitional seasons compared to west season and east season. Chlorophyll-a concentration in area of research ranging from 0,22 $\mathrm{mg} / \mathrm{m}^{3}-1,15 \mathrm{mg} / \mathrm{m}^{3}$. Chlorophyll-a concentration value each month fluctuates follow wind of progress. Maximum value of chlorophyll-a concentration happening in wesh season and minimum value occurs in transitional season 2. Layang scad, banyar fish and eastern little tuna has a negative response to sea surface temperature especially in east season. As for sardine fish and fringescalle sardine show absence of a direct relationshop between sea surface temperature with CPUE value catches. Sardine fish and fringescalle sardine show any positive response to rising chlorophyll-a concentration, while for layang scad, banyar fish and eastern little tuna an increase value of chlorophyll-a concentration does not have a direct impact on rising CPUE value of third type of this fish.
\end{abstract}

Keywords: Chlorophyll-a concentration, sea surface temperature, CPUE pelagic fish, Java Sea

\begin{abstract}
ABSTRAK
Penelitian ini bertujuan untuk mempelajari variasi spasial dan temporal konsentrasi klorofil-a dan suhu permukaan laut serta hubungannya dengan hasil tangkapan ikan pelagis di Laut Jawa. Hasil penelitian menunjukkan dalam tahun 2006-2010 terjadi kenaikan suhu permukan laut sebesar $1{ }^{\circ} \mathrm{C}$ dimana suhu permukan laut rata-rata bulanan berkisar antara $27,9^{\circ} \mathrm{C}-31,4^{\circ} \mathrm{C}$. Suhu permukaan laut relatif lebih tinggi pada saat musim peralihan dibandingkan dengan musim barat dan musim timur. Konsentrasi klorofil-a pada wilayah penelitian berkisar antara $0,22 \mathrm{mg} / \mathrm{m}^{3}-1,15 \mathrm{mg} / \mathrm{m}^{3}$. Nilai konsentrasi klorofil-a setiap bulannya berfluktuasi mengikuti musim angin yang sedang berlangsung. Nilai maksimum konsentrasi klorofil-a terjadi pada musim Barat dan nilai minimumnya terjadi pada musim peralihan 2. Ikan layang, banyar dan tembang memiliki respon yang negatif terhadap suhu permukaan laut terutama pada musim timur. Sedangkan untuk ikan lemuru dan ikan tembang menunjukkan tidak adanya hubungan langsung antara suhu permukaan laut dengan nilai CPUE hasil tangkapan. Ikan lemuru dan ikan tembang menunjukkan adanya respon positif terhadap naiknya konsentrasi klorofil-a, sedangkan untuk ikan layang, banyar dan tongkol kenaikan nilai konsentrasi klorofil tidak berdampak langsung pada naiknya nilai CPUE ketiga jenis ikan ini.
\end{abstract}

Kata kunci: Konsentrasi klorofil-a, suhu permukan laut, CPUE ikan pelagis, Laut Jawa

\section{PENDAHULUAN}

Laut Jawa merupakan salah satu perairan yang kaya akan potensi ikan pelagis kecil. Menurut Wijopriono (2008), pada periode tahun 1999-2002 sumber daya ikan pelagis di perairan Laut Jawa mengalami variasi dalam sebaran dan kelimpahan menurut musim. Musimmusim penangkapan ikan di Laut Jawa dipengaruhi oleh dua massa air yang mendominasi perairan Laut Jawa. Kedua massa air ini berasal dari massa air Laut Cina Selatan dan massa air Laut Flores (Hadikusumah, 2008). Kedua massa air ini mempengaruhi pola persebaran parameter oseanografi seperti kandungan klorofil-a dan suhu permukaan laut (SPL) yang berdampak pada pola musim penangkapan ikan di Laut Jawa. 
Penginderaan jauh merupakan suatu teknik yang dapat diaplikasikan untuk pengamatan parameter oseanografi perairan seperti kandungan klorofil-a dan SPL baik secara spasial maupun temporal. Salah satu satelit penginderaan jauh yang dapat mendeteksi kandungan klorofil-a dan SPL adalah satelit Aqua Moderate Resolution Imaging Spectroradiometer (MODIS). Data satelit Aqua MODIS dapat digunakan untuk menentukan konsentrasi klorofil-a dan sebaran SPL di perairan Laut Jawa. Variasi kondisi oseanografi Laut Jawa berhubungan dengan variasi hasil tangkapan ikan. Oleh karena itu, pemantauan karakteristik parameter oseanografi penting dilakukan sebagai salah satu aspek dalam mengkaji pengelolaan perikanan di Laut Jawa.

Penelitian ini bertujuan untuk menganalisis variasi spasial dan temporal konsentrasi klorofil-a dan sebaran SPL di perairan Laut Jawa serta faktor-faktor yang mempengaruhinya, dan menganalisis hubungan konsentrasi klorofil-a dan SPL dengan hasil tangkapan ikan pelagis di perairan Laut Jawa.

\section{METODOLOGI PENELITIAN}

Lokasi penelitian terletak di perairan Laut Jawa pada koordinat $106^{0}$ BT $-116^{0}$ BT dan $3^{0}$ LS $-7^{0}$ LS. Data yang digunakan meliputi beberapa data seperti: data klorofil-a dan SPL rata-rata mingguan dari citra satelit Aqua MODIS level-3 dengan resolusi $4 \times 4 \mathrm{~km}$, data angin bulanan selama 5 tahun (20062010), data curah hujan bulanan selama 5 tahun, dan data hasil tangkapan ikan yang didaratkan di PPN Pekalongan, Jawa Tengah (2006-2010). Pengolahan data SPL dan klorofil-a menggunakan perangkat lunak SeaDas dengan sistem operasi Linux Ubuntu 10.04. Hasil pengolahan berupa data dalam format* ASCII yang kemudian ditampilkan kembali dalam bentuk grafik time series dan dalam bentuk gambar sebaran spasial.

Produktifitas suatu alat tangkap dapat diduga dengan melihat hubungan antar hasil tangkapan (catch) dengan upaya penangkapan (effort), yang disebut Catch Per Unit Effort (CPUE).
Dalam penelitian ini data catch merupakan data hasil tangkapan ikan pelagis yang didaratkan dari sejumlah kapal yang merupakan upaya penangkapan (effort). Hal ini dapat digambarkan melalui persamaan sebagai berikut (Gulland, 1983 dalam Syarif et al., 2009):

$$
C P U E=\frac{C_{t}}{E_{t}}
$$

Keterangan :

$$
\begin{array}{ll}
C P U E & =\text { Hasil per upaya tangkap } \\
C_{t} & =\text { Hasil tangkapan pada } \\
& \text { bulan ke- } \mathrm{t} \\
E_{t} & =\text { Upaya penangkapan pada } \\
& \text { bulan ke-t }
\end{array}
$$

Bila di suatu daerah terdapat berbagai alat tangkap maka salah satunya harus dipakai sebagai standar dan alat tangkap lain distandarisasi terhadap alat tangkap tersebut. Hal ini disebabkan karena kemampuan tangkap tiap alat tangkap berbeda-beda. Alat tangkap yang menjadi standar adalah alat tangkap yang memiliki produktifitas penangkapan rata-rata paling tinggi. Kemampuan penangkapan atau fishing power index (FPI) dihitung dengan membandingkan produktifitas penangkapan masing-masing alat tangkap terhadap produktifitas alat tangkap standar. Rumus yang dipakai untuk menghitung FPI adalah sebagai berikut (Gulland, 1983 dalam Syarif et al., 2009):

$$
F P I=\frac{C P U E_{i d s t}}{C P U E_{i s t}}
$$

Keterangan :

$$
\begin{aligned}
F P I= & \text { Fishing Power Index } \\
C P U E_{i d s t}= & \text { CPUE alat tangkap yang } \\
& \text { akan distandarisasi } \\
C P U E_{i s t}= & \text { CPUE alat tangkap } \\
& \text { standar }
\end{aligned}
$$

Perhitungan upaya penangkapan standar diperoleh dari hasil kali antara nilai FPI masing-masing alat tangkap yang distandarisasi dengan upaya penangkapan yang akan distandarisasi.

$$
f s=F P I \times f d s t
$$

Keterangan :

$$
\begin{aligned}
f_{S}= & \text { upaya penangkapan hasil } \\
& \text { standarisasi } \\
f_{d s t}= & \text { upaya penangkapan yang } \\
& \text { akan distandarisasi }
\end{aligned}
$$


Nilai CPUE dihitung kembali dengan upaya penangkapan yang baru yaitu niai upaya penangkapan setelah dilakukan standarisasi upaya penangkapan.

$$
C P U E_{S i}=\frac{C_{i}}{E_{i}}
$$

Keterangan :

$$
\begin{aligned}
C P U E_{S i} & =\text { Hasil per upaya tangkap } \\
& \text { yang telah distandarisasi } \\
& \text { bulan ke } \mathrm{i} \\
C_{i} \quad & \text { Hasil tangkapan pada } \\
& \text { bulan ke } \mathrm{i} \\
E_{i} \quad & \text { Upaya penangkapan pada } \\
& \text { bulan ke } \mathrm{i}
\end{aligned}
$$

\section{HASIL DAN PEMBAHASAN}

\subsection{Distribusi SPL secara Spasial dan Temporal}

Pola pergerakan SPL di Laut Jawa mengikuti pola musim angin yang terjadi di Laut Jawa, yaitu: musim barat, timur, dan peralihan. Sebaran SPL secara spasial di Laut Jawa dapat dilihat pada Gambar 1.

SPL Laut Jawa berdasarkan sebararan spasial citra satelit MODIS berkisar antara $27^{\circ} \mathrm{C}-31^{\circ} \mathrm{C}$. Hal ini tidak berbeda jauh dengan suhu permukaan laut Indonesia menurut Nontji (2005), yaitu: berkisar antara $28^{\circ} \mathrm{C}-31^{\circ} \mathrm{C}$. SPL di Laut Jawa mengikuti pola angin musim yang terjadi di perairan Indonesia. Musim Barat memperlihatkan masuknya SPL bernilai rendah dari Laut Cina Selatan melewati Laut Jawa menuju Selat Makassar dan Laut Flores. Sedangkan pada musim timur terjadi peristiwa sebaliknya dimana SPL bernilai rendah memasuki perairan Laut Jawa dari Selat Makassar dan Laut Flores dan mengarah ke Laut Cina Selatan. Pada musim barat dan musim timur terjadi penurunan SPL akibat pergerakan massa air yang disebabkan oleh angin musim ini. Peningkatan SPL di Laut Jawa terjadi pada musim peralihan 1 dan 2 dimana pengaruh angin musim mulai berkurang sehingga terjadi pemanasan kolom perairan oleh sinar matahari.

SPL Laut Jawa secara deret waktu dapat dilihat pada Gambar 2. Pada musim barat (Desember - Februari) dalam kurun waktu 5 tahun, SPL Laut Jawa berkisar antara $28,49^{\circ} \mathrm{C}-30,65^{\circ} \mathrm{C}$, sedangkan untuk musim timur (Juli Agustus) SPL berkisar pada nilai $27,96^{\circ} \mathrm{C}-30,10^{\circ} \mathrm{C}$. Untuk musim peralihan rata-rata SPL relatif lebih tinggi jika dibandingkan dengan dengan musim barat dan musim timur. Pada musim peralihan 1 (Maret - Mei) ratarata SPL berkisar antara $29,46^{\circ} \mathrm{C}-$ $31,49^{\circ} \mathrm{C}$ dan musim peralihan 2 (September - November) berada pada nilai suhu $28,01^{\circ} \mathrm{C}-30,65^{\circ} \mathrm{C}$. Secara umum trend perubahan SPL yang terjadi di Laut Jawa dalam kurun waktu penelitian menunjukkan kenaikan. Kenaikan SPL di Laut Jawa ini berkisar $1^{\circ} \mathrm{C}$ dalam jangka waktu 5 tahun atau $0.2^{\circ} \mathrm{C}$ setiap tahunnya. Siregar dan Gaol (2010) menyebutkan telah terjadi kenaikan SPL di perairan Laut Jawa sebesar $0,1^{\circ} \mathrm{C}$ setiap tahunnya dari tahun 2001-2010. Kenaikan SPL ini diduga disebabkan oleh faktor-faktor meteorologi seperti kenaikan suhu udara.

\subsection{Distribusi Klorofil-a secara Spasial dan Temporal}

Kandungan klorofil-a di Laut Jawa secara spasial dapat dilihat pada Gambar 3. Klorofil-a terkonsentrasi di daerah pesisir perairan dan konsentrasinya semakin berkurang menuju arah lepas pantai. Konsentrasi klorofil-a paling besar terdapat pada pesisir pantai Selatan Pulau Kalimantan dan pesisir pantai Utara Pulau Jawa.

Pada perairan lepas pantai Laut Jawa memperlihatkan konsentrasi klorofil-a yang hampir seragam dengan nilai konsentrasi klorofil-a kecil dari 0.05 $\mathrm{mg} / \mathrm{m}^{3}$. Tingginya konsentrasi klorofil-a di wilayah pesisir ini terjadi karena terakumulasinya zat hara yang dibawa oleh aliran sungai menuju perairan laut di wilayah pesisir khususnya di pesisir pantai selatan Pulau Kalimantan. Musim barat dan musim peralihan 1 merupakan musim dimana konsentrasi klorofil-a cukup tinggi. Hal ini diduga terjadi karena tingginya curah hujan yang turun di Indonesia sehingga menyebabkan banyaknya zat hara yang masuk ke perairan laut melalui aliran sungai. Sebaliknya pada musim timur dan peralihan 2 terjadi penurunan konsentrasi klorofil-a di Laut Jawa. 


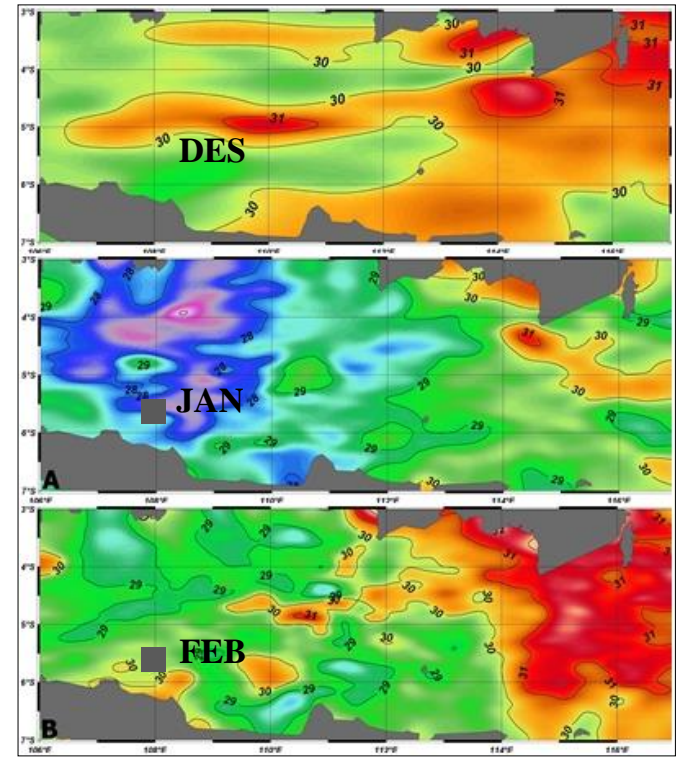

Musim Barat

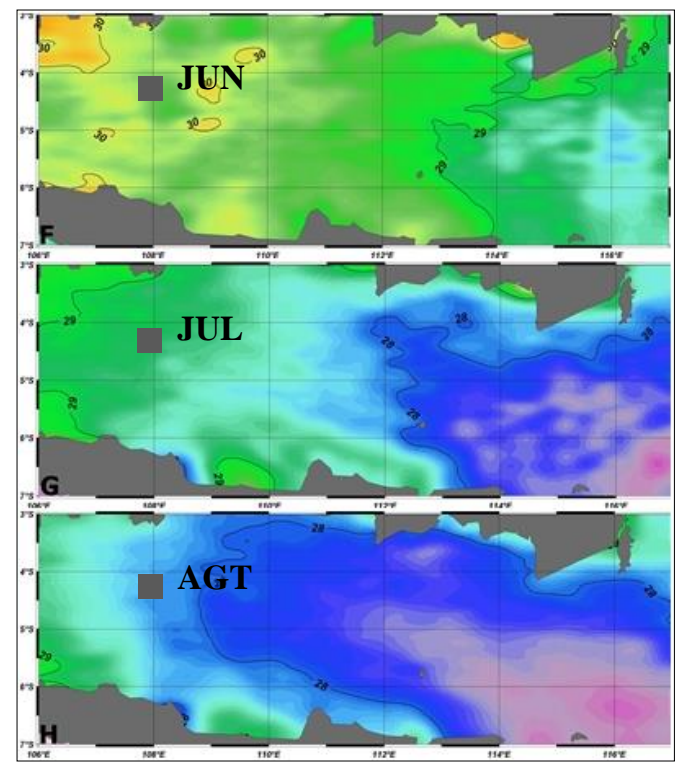

Musim Timur

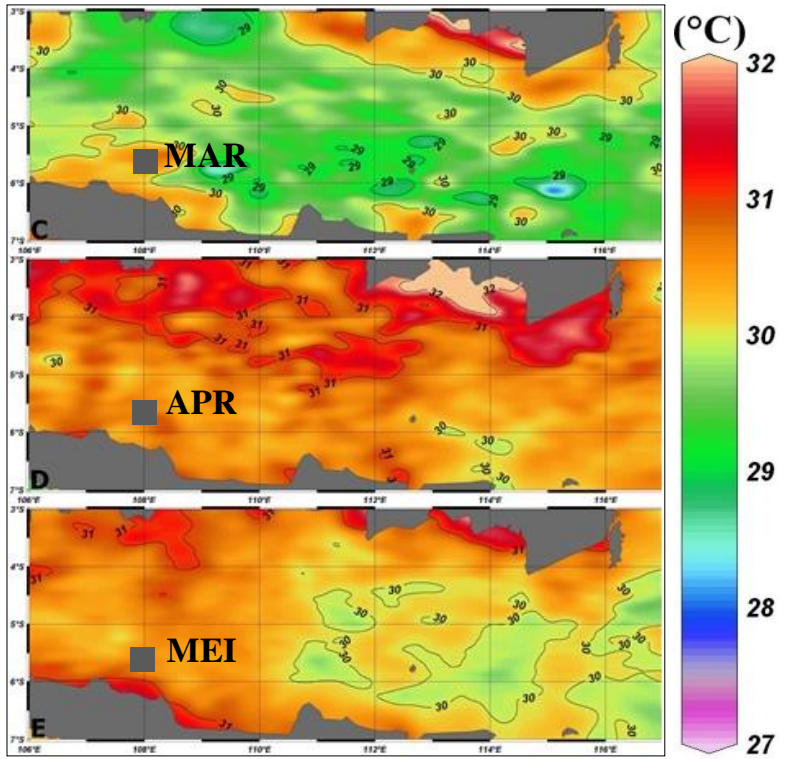

Musim Peralihan 1

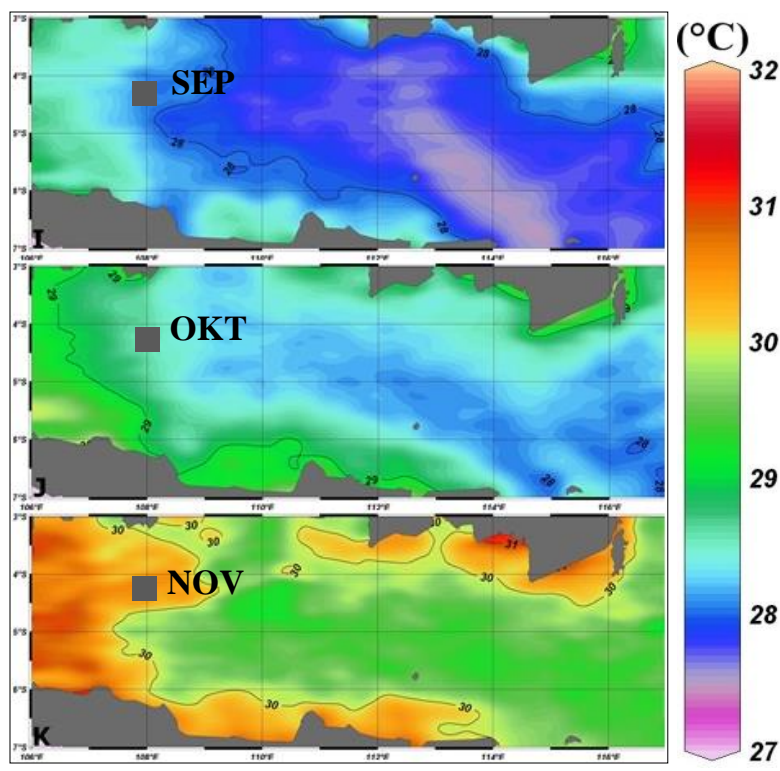

Musim Peralihan 2

Gambar 1. Distribusi SPL rata-rata bulanan Januari 2006 - Desember 2006

Menurut Nontji (2005), musim barat merupakan musim angin yang membawa banyak hujan sedangkan musim timur sedikit membawa hujan.

Secara derat waktu kandungan klorofil-a yang dapat terdeteksi dari citra satelit Aqua MODIS dapat dilihat pada Gambar 4. Secara keseluruhan, trend konsentrasi klorofil yang terdapat di
Laut Jawa menurun dalam kurun waktu 5 tahun terakhir. Kandungan konsentrasi klorofil rata-rata di perairan Laut Jawa berkisar antara $0,22 \mathrm{mg} / \mathrm{m}^{3}-1,15$ $\mathrm{mg} / \mathrm{m}^{3}$. Nilai konsentrasi klorofil setiap bulannya berfluktuasi mengikuti musim angin yang sedang berlangsung dan mencapai puncaknya pada musim barat. 


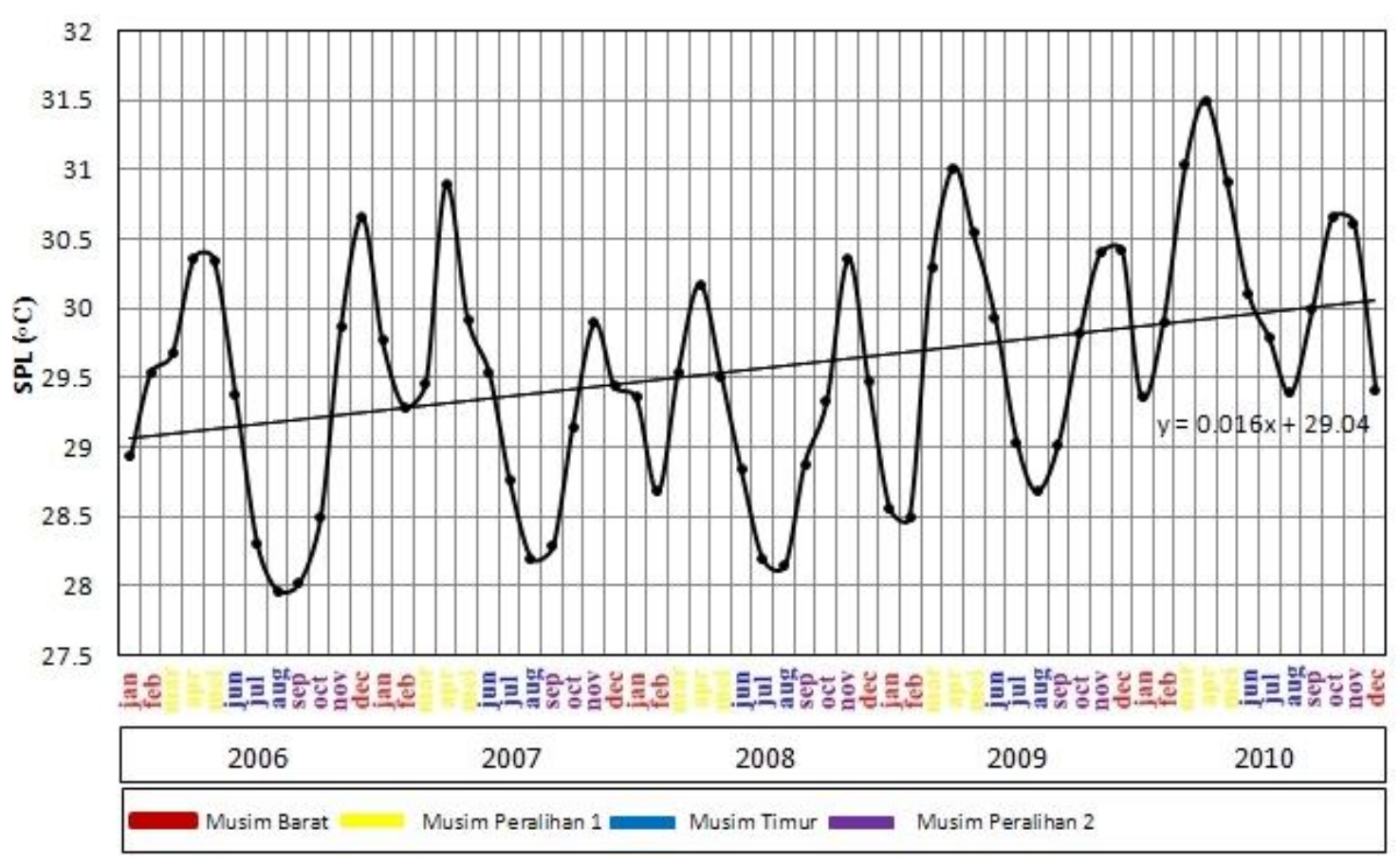

Gambar 2. Fluktuasi SPL rata-rata bulanan Januari 2006 - Desember 2010

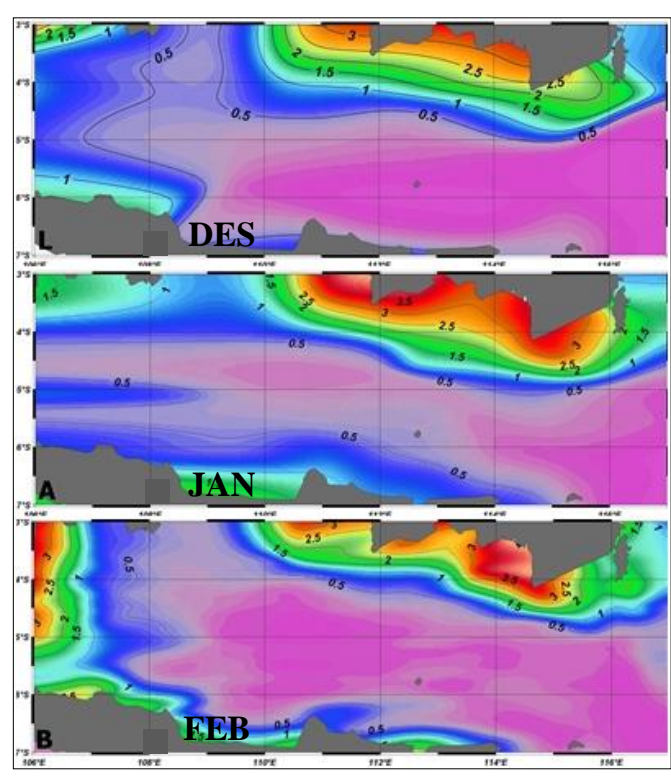

a. Musim Barat

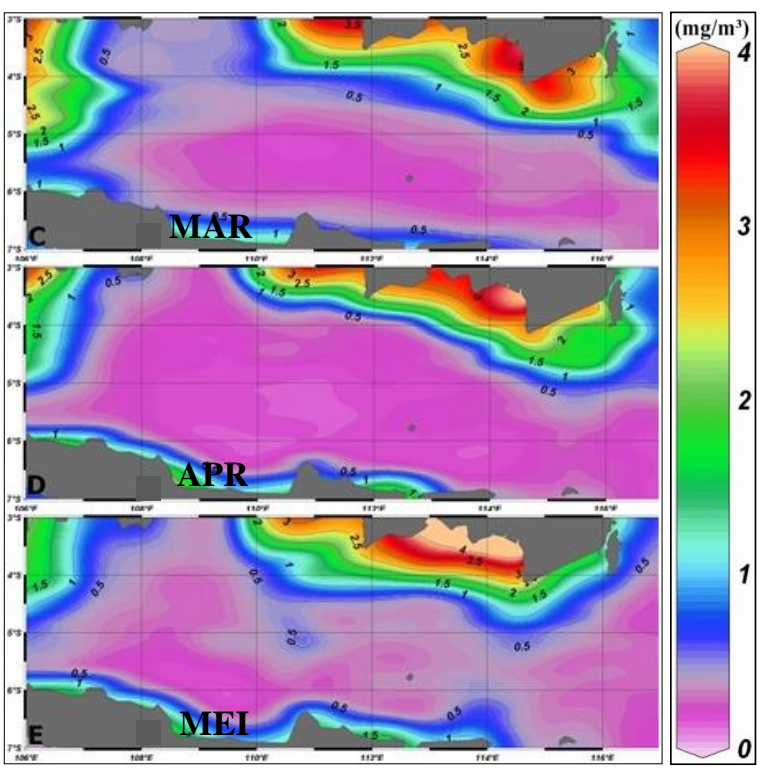

Musim Peralihan 1

Gambar 3a. Distribusi klorofil-a rata-rata bulanan Januari 2006 - Desember 2006 


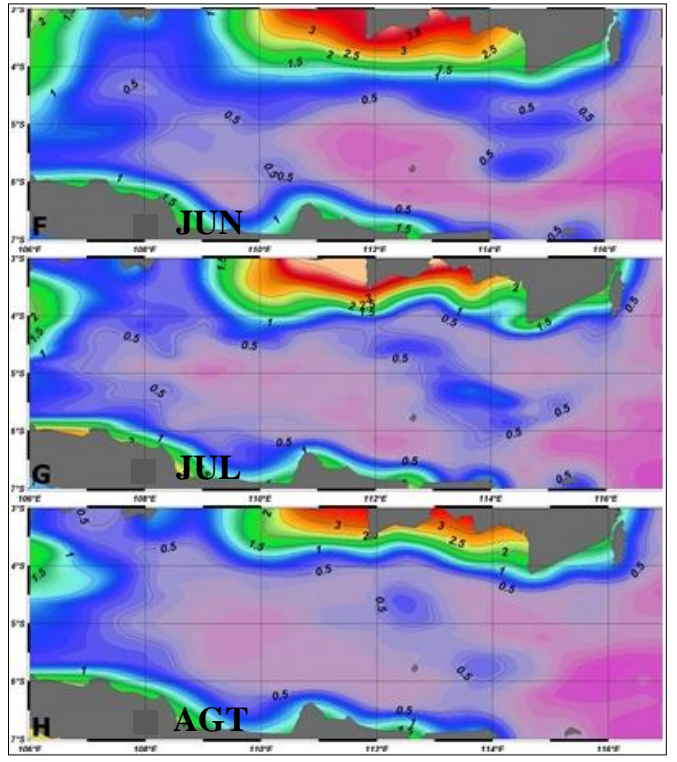

b. Musim Timur

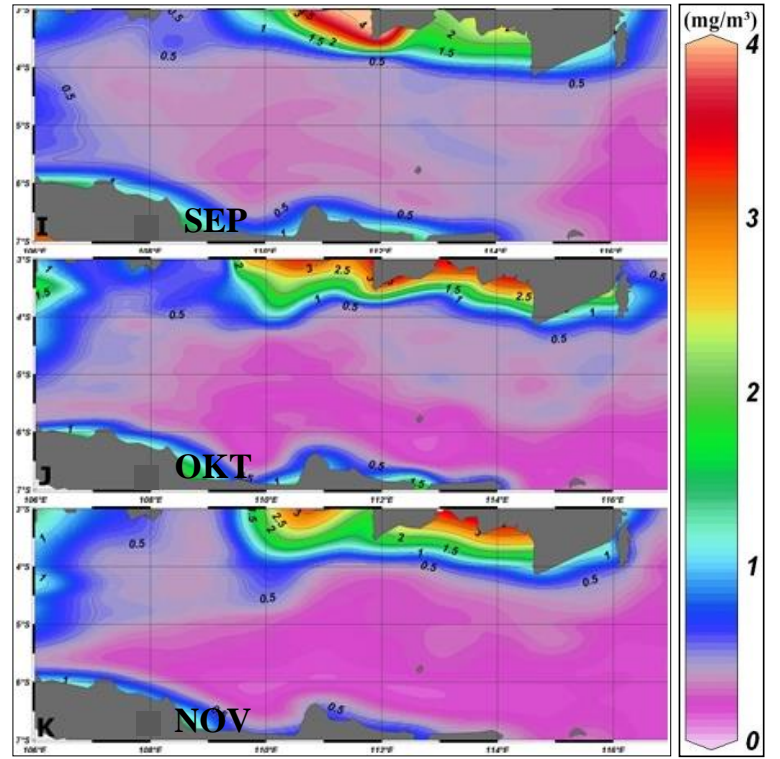

Musim Peralihan 2

Gambar 3b. Distribusi klorofil-a rata-rata bulanan Januari 2006 - Desember 2006

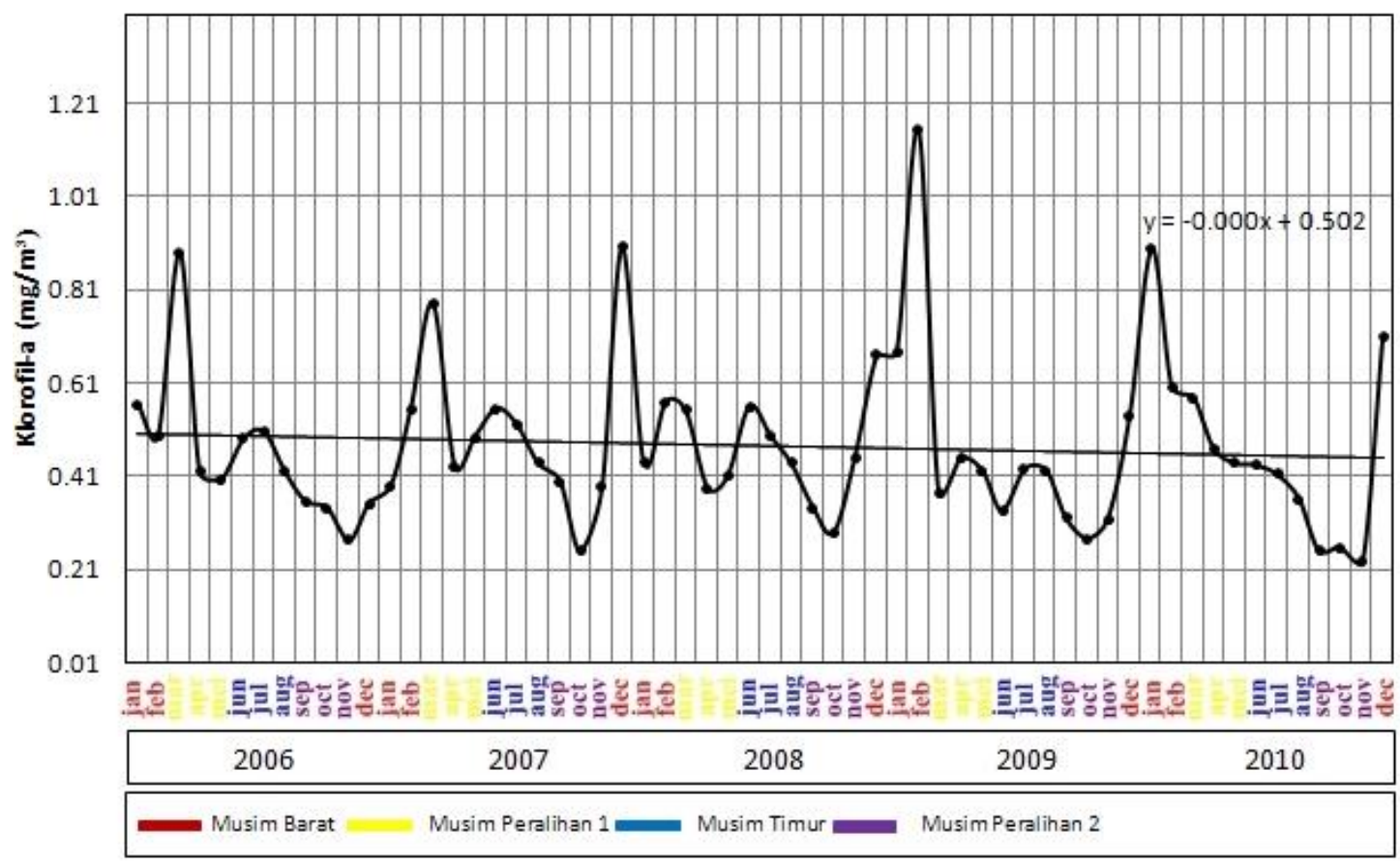

Gambar 4. Fluktuasi klorofil-a rata-rata bulanan Januari 2006 - Desember 2010

\subsection{Tangkapan per Unit Upaya (CPUE) Ikan Pelagis Utama di Laut Jawa}

Produksi hasil tangkapan yang didaratkan di PPN Pekalongan didominasi oleh lima jenis ikan, yaitu: ikan layang (Decapterus Spp.), lemuru (Sardinella sirm), tongkol (Enthynnus affinis), banyar/kembung lelaki (Rastrelliger kanagurta), dan tembang
(Sardinella Spp). Komoditas tangkapan utama yang didaratkan adalah ikan layang. Menurut penelitian Zamroni dan Suwarso (2009) ikan layang (Decapterus russelli dan D. macrosoma) merupakan spesies yang dominan dengan persentase mencapai $42-58 \%$ dari total hasil tangkapan. Nilai CPUE tangkapan 
ikan pelagis utama di Laut Jawa dapat dilihat pada Gambar 5 .

Dalam rentang waktu tahun 2006-2010 terlihat nilai CPUE ikan layang cenderung menunjukkan trend yang menurun. Nilai CPUE ikan layang terbesar terjadi pada bulan September 2009 dengan nilai 11,94 ton/trip sedangkan nilai CPUE terendah ikan layang terjadi pada bulan Juni 2010 dengan nilai 0,12 ton/trip. Hal ini diperkuat dengan hasil penelitian Nugroho (2006) bahwa telah terjadi penurunan produksi ikan layang yang berasal dari perikanan pukat cincin yang tertangkap di perairan Laut Jawa dan sekitarnya.

Nilai CPUE ikan lemuru dan ikan tongkol memperlihatkan trend yang yang meningkat. Nilai CPUE ikan lemuru tertinggi terjadi antara bulan DesemberFebruari (Musim Barat) setiap tahunnya. Sedangkan untuk nilai CPUE terendah terjadi antara bulan Oktober-November. Untuk ikan tongkol, kenaikan nilai CPUE terlihat terjadi sekitar bulan Februari-April dan bulan AgustusOktober. Nilai CPUE ikan tongkol terendah terjadi antara bulan Juni-Juli. Ikan banyar memperlihatkan trend nilai
CPUE yang menurun. Nilai CPUE tertinggi ikan banyar rata-rata tiap tahunnya terjadi sekitar bulan MaretMei (musim peralihan1) dan bulan Juli Agustus (musim timur). Nilai CPUE terendah ikan banyar terjadi antara bulan Desember-Februari. Untuk ikan tembang, nilai CPUE tertinggi terjadi sekitar bulan April-Juni. Nilai CPUE terendah ikan tembang terjadi sekitar bulan Desember-Februari. Nilai CPUE ikan tembang memperlihatkan trend yang meningkat.

\subsection{Hubungan antara SPL dengan Hasil Tangkapan}

Pengaruh SPL terhadap nilai CPUE hasil tangkapan ikan pelagis berbeda-beda antara satu ikan dengan ikan yang lainnya. Hal ini dapat terlihat pada Gambar 6. Komoditas ikan layang dan ikan banyar merupakan ikan yang bersifat stenohalin yaitu hidup pada perairan dengan salinitas yang sempit. Kedua jenis ikan ini hidup optimal pada salinitas perairan yang tinggi. Masuknya massa air yang bersuhu rendah dan bersalinitas tinggi dari Laut Flores dan Selat Makassar pada musim timur ke Laut Jawa membawa dampak terhadap
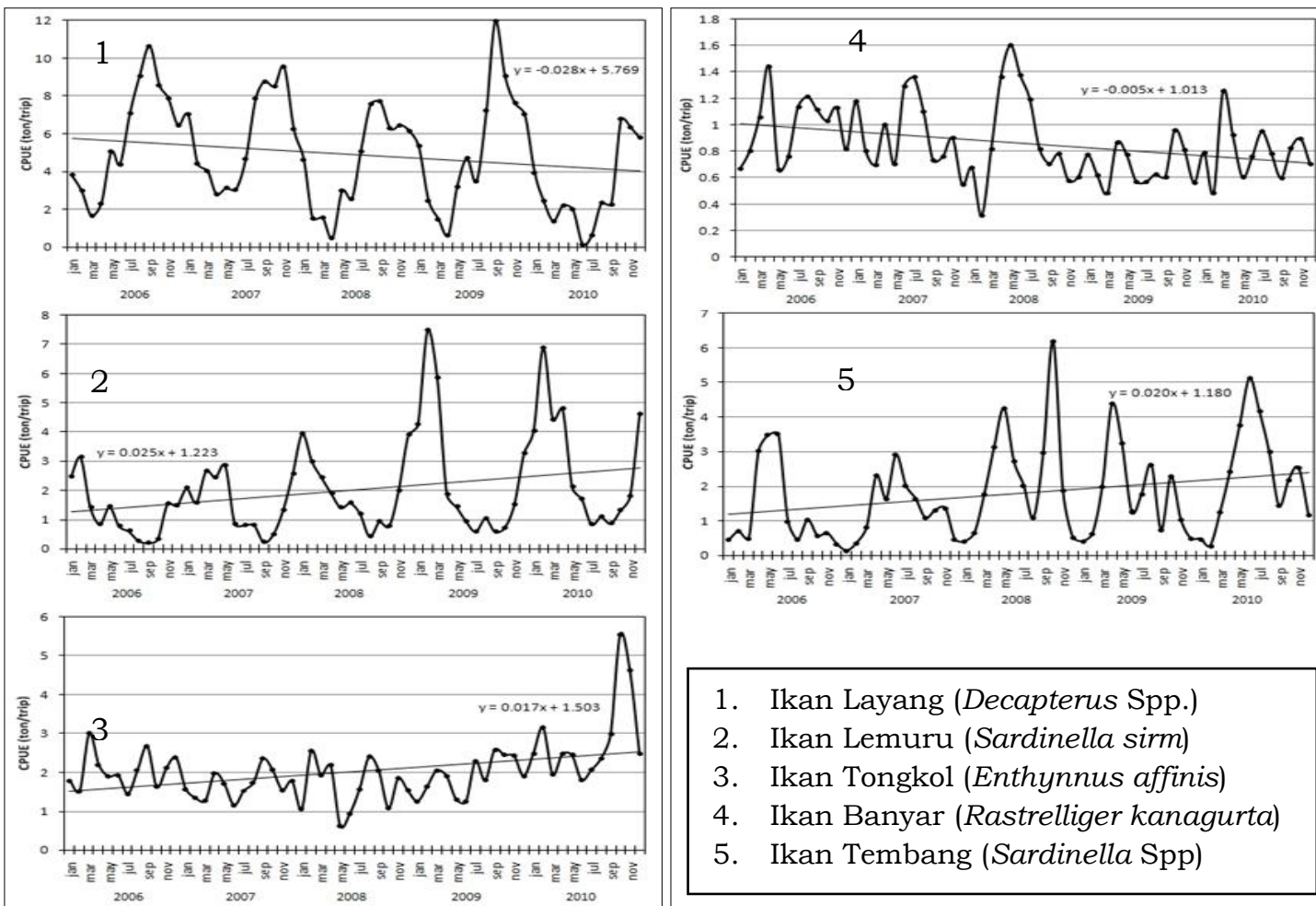

1. Ikan Layang (Decapterus Spp.)

2. Ikan Lemuru (Sardinella sirm)

3. Ikan Tongkol (Enthynnus affinis)

4. Ikan Banyar (Rastrelliger kanagurta)

5. Ikan Tembang (Sardinella Spp)

Gambar 5. Catch Per Unit Effort (CPUE) ikan pelagis utama di Laut Jawa 
hasil tangkapan kedua jenis ikan ini. Salinitas yang tinggi pada musim timur dan peralihan 2 menyebabkan tingginya CPUE ikan layang dan ikan banyar. Sebaliknya pada musim barat dan peralihan 1 SPL Laut Jawa naik dan salinitas perairan turun sehingga nilai CPUE ikan layang dan ikan banyar turun. Dari Gambar 6 dapat dilihat turunnya SPL bulan Juni-September 2007 (musim timur) diiringi naiknya nilai CPUE ikan layang, sebaliknya naiknya SPL pada bulan Maret-Mei 2008 (musim peralihan 1) diiringi turunnya nilai CPUE ikan layang.

Untuk jenis ikan tongkol nilai CPUE ikan tongkol menunjukkan pola dimana saat SPL naik, nilai CPUE ikan tongkol akan naik sebaliknya saat SPL turun, nilai CPUE ikan tongkol akan turun. Ikan lemuru dan ikan tembang merupakan jenis ikan pelagis yang keberadaannya tergantung pada plankton yang merupakan makanan utama kedua jenis ikan ini (Nontji, 2005). Nilai CPUE ikan lemuru dan ikan tembang cenderung naik pada musim barat dan musim peralihan 1 serta akan turun pada musim timur dam musim peralihan 2. Pola ini mengindikasikan tidak adanya hubungan langsung antara SPL dengan nilai CPUE ikan lemuru dan ikan tembang.

\subsection{Hubungan antara Konsentrasi Klorofil-a dengan Hasil Tangkapan}

Kandungan klorofil-a pada suatu perairan sangat erat kaitannya dengan rantai makanan. Kandungan klorofil-a yang tinggi pada perairan akan meningkatkan produktifitas zoo plankton, sehingga tercipta suatu rantai makanan yang menunjang produktifitas ikan di perairan. Ikan layang dan ikan banyar merupakan jenis ikan pelagis yang keberadaanya tidak secara langsung dipengaruhi oleh klorofil-a. Secara deskriptif terlihat pada kedua jenis ikan pelagis ini akan menunjukkan kecenderungan dimana nilai CPUE ikan akan naik saat konsentrasi klorofil-a rendah terutama saat musim timur. Sebagaimana telah disebutkan sebelumnya, musim timur merupakan musim angin yang membawa massa air yang bersalinitas tinggi dan bersuhu rendah masuk ke Laut Jawa.

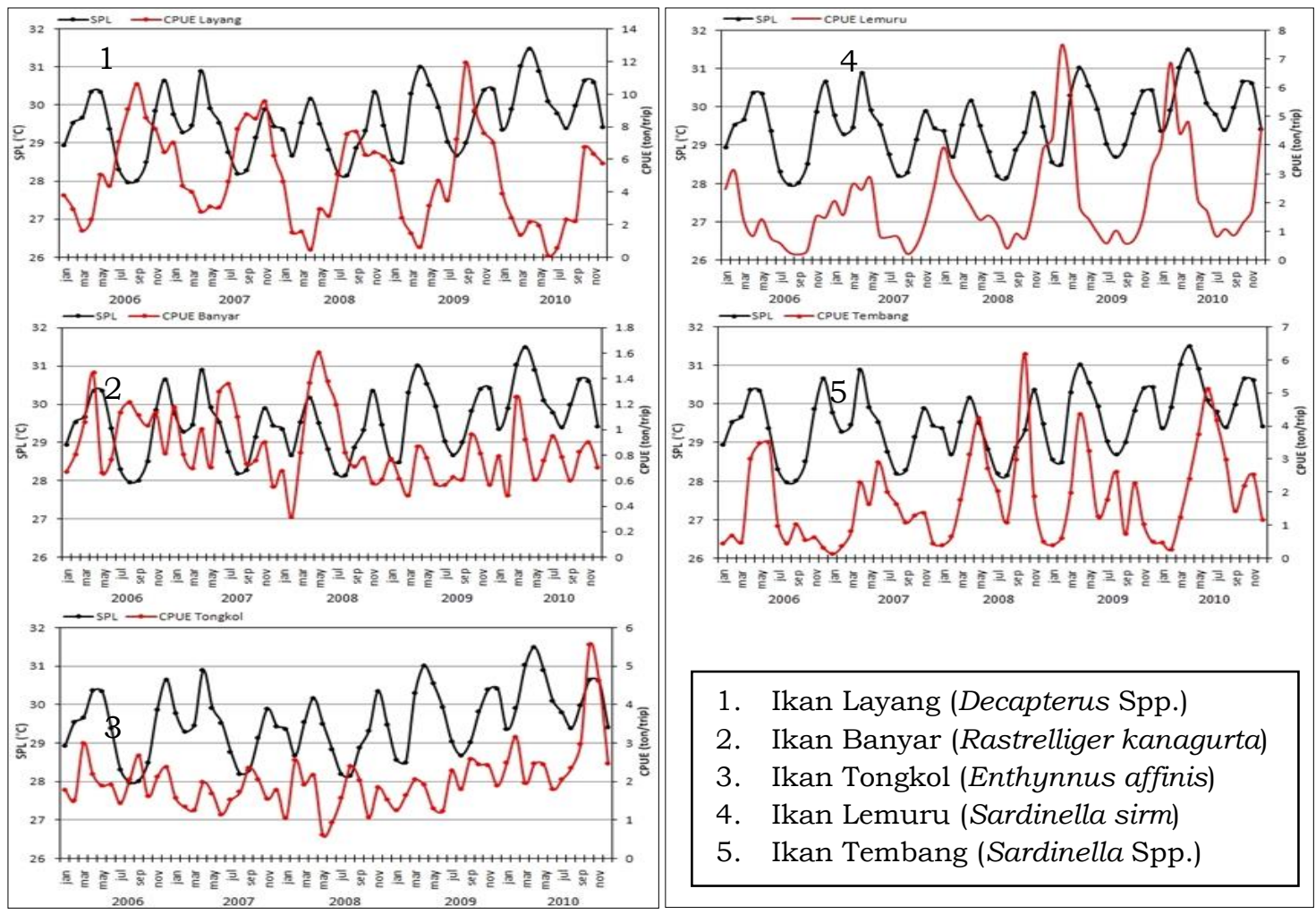

Gambar 6. Hubungan antara SPL dengan hasil tangkapan ikan pelagis utama di Laut Jawa 
Kondisi ini merupakan kondisi yang sangat mendukung keberadaan ikan layang dan ikan banyar.

Keberadaan ikan tongkol secara langsung kurang dipengaruhi oleh keberadaan konsentrasi klorofil-a. Nilai CPUE ikan tongkol akan meningkat sekitar musim peralihan 1 dan peralihan 2. Pada musim peralihan 1 konsentrasi klorofil-a cenderung tinggi sedangkan sebaliknya pada musim peralihan 2 konsentrasi klorofil-a di Laut Jawa rendah.

Ikan lemuru dan ikan tembang merupakan jenis ikan pelagis yang keberadaannya tergantung pada konsentrasi klorofil-a. Kenaikkan konsentrasi klorofil-a perairan akan diiringi dengan kenaikkan nilai CPUE kedua jenis ikan ini. Naiknya nilai konsentrasi klorofil-a tidak langsung berdampak pada naiknya nilai CPUE, akan tetapi membutuhkan beberapa waktu sehingga klorofil yang ada telah dimanfaatkan oleh zooplankton sebagai sumber makanan. Untuk ikan lemuru terlihat kenaikan konsentrasi klorofil-a langsung diiringi dengan kenaikan nilai CPUE seperti pada musim barat tahun 2008, 2009, dan 2010. Selanjutnya penurunan konsentrasi klorofil-a pada musim timur juga diiringi dengan penurunan nilai CPUE ikan lemuru. Ikan tembang memiliki respon yang hampir sama dengan ikan lemuru terhadap konsentrasi klorofil-a. Tetapi kenaikan nilai CPUE ikan tembang terjadi beberapa waktu setelah terjadi kenaikan konsentrasi klorofil-a.

Terdapat rentang waktu sekitar satu sampai dua bulan antara mulai naiknya nilai CPUE ikan tembang dengan konsentrasi klorofil-a maksimum diperairan Laut Jawa. Konsentrasi klorofil-a mencapai puncaknya pada musim barat sedangkan kenaikan nilai CPUE baru terjadi pada awal musim peralihan 1. Hal ini dapat dilihat pada bulan Februari-Juni 2006 dan bulan Desember 2009-Juni 2010.
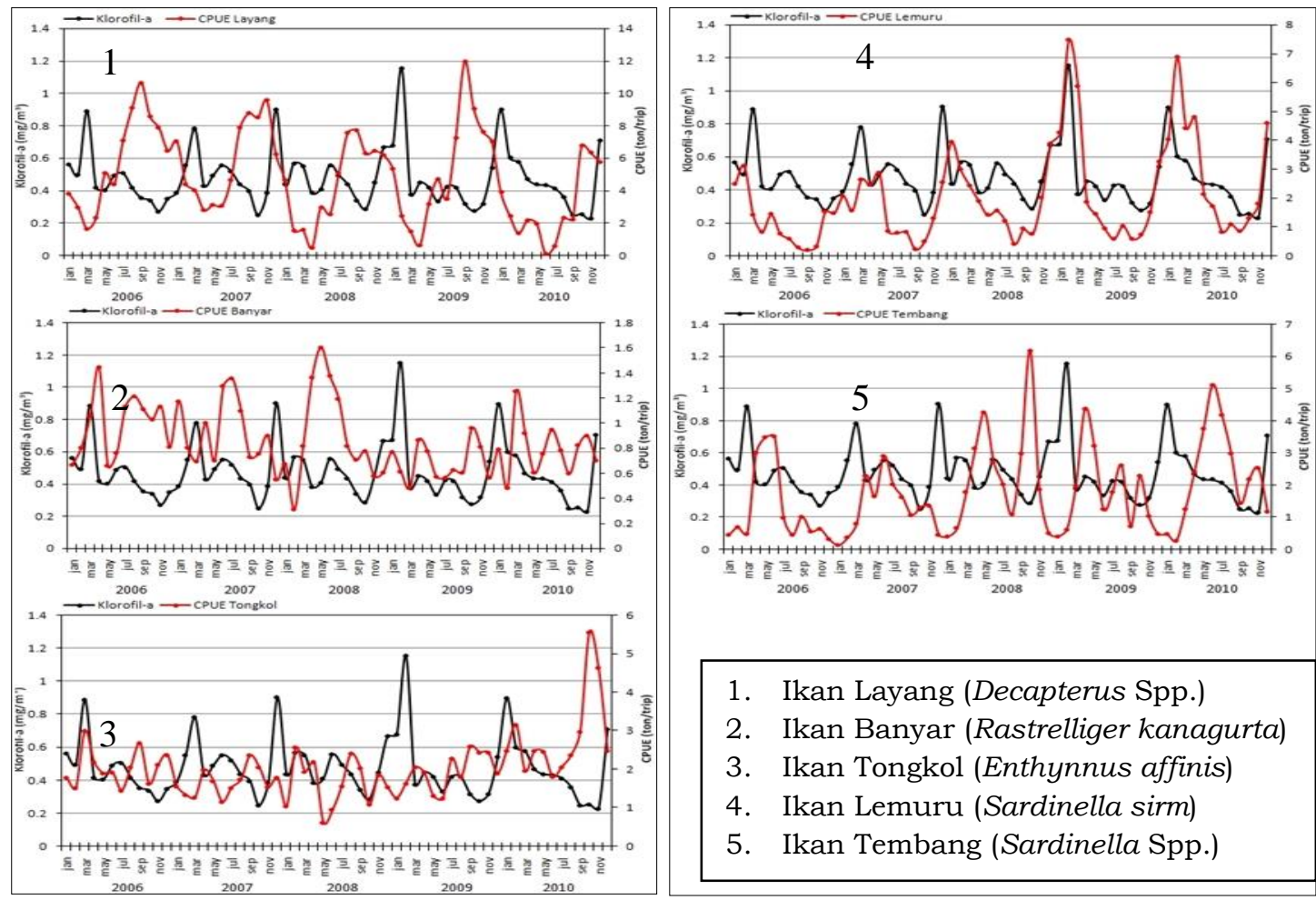

Gambar 7. Hubungan antara klorofil-a dengan hasil tangkapan ikan pelagis utama di Laut Jawa 
SPL rata-rata bulanan di Laut Jawa dari citra satelit Aqua MODIS tahun 2006 - 2010 berkisar antara $27,9^{\circ} \mathrm{C}-31,4^{\circ} \mathrm{C}$. Penyebaran SPL di Laut Jawa mengikuti pola angin musim yang terjadi di perairan Indonesia dimana SPL cenderung turun pada musim barat dan timur serta naik pada musim peralihan 1 dan peralihan 2 .

Secara deret waktu, terlihat terjadinya trend kenaikan SPL di Laut Jawa dalam kurun waktu 5 tahun terakhir sebesar $1^{\circ} \mathrm{C}$ atau $0.2^{\circ} \mathrm{C}$ setiap tahunnya. Konsentrasi klorofil-a berkisar antara $0,22 \mathrm{mg} / \mathrm{m}^{3}-1,15$ $\mathrm{mg} / \mathrm{m}^{3}$. Nilai konsentrasi klorofil-a setiap bulannya berfluktuasi mengikuti musim angin yang sedang berlangsung.

Konsentrasi klorofil-a tertinggi terjadi pada musim barat dan terendah terjadi pada musim peralihan 2. Secara keseluruhan trend konsentrasi klorofil-a di Laut Jawa terlihat menurun.

Hubungan antara SPL dan konsentrasi klorofil-a dengan komoditas ikan pelagis menunjukkan respon yang berbeda antara satu jenis ikan dengan jenis ikan lainnya. Ikan layang dan banyar memiliki respon yang negatif terhadap SPL terutama pada musim timur. Hal ini diduga disebabkan karena masuknya massa air yang bersuhu rendah dan bersalinitas tinggi dari Laut Flores dan Selat Makassar pada musim timur. Ikan tongkol memperlihatkan pola dimana naiknya SPL menyebabkan naiknya nilai CPUE sebaliknya turunnya SPL menyebabkan turunnya nilai CPUE ikan tongkol. Sedangkan untuk ikan lemuru dan ikan tembang menunjukkan tidak adanya hubungan langsung antara SPL dengan nilai CPUE hasil tangkapan.

Respon ikan pelagis terhadap konsentrasi klorofil-a menunjukkan adanya respon positif pada komoditas ikan lemuru dan ikan tembang dimana kenaikan konsentrasi klorofil-a diikuti dengan kenaikan nilai CPUE. Untuk ikan layang, banyar dan tongkol kenaikan nilai konsentrasi klorofil-a tidak langsung berdampak pada naiknya nilai CPUE ketiga jenis ikan ini.

\section{DAFTAR PUSTAKA}

Hadikusumah. 2008. Karakteristik Parameter Fisika dan Kandungan Klorofil-a di Laut Jawa. Jurnal Ilmu Kelautan. 13 (2): 103-112.

Nontji, A. 2005. Laut Nusantara. Djambatan. Jakarta.

Nugroho, D. 2006. Kondisi Trend Biomassa Ikan Layang (Decapterus spp.) di Laut Jawa dan Sekitarnya. Jurnal Penelitian Perikanan Indonesia. 12 (3): 167-174.

Sharif, A., S. Syakila, dan W. D. Lubayasari. 2009. Pendugaan stok ikan layur (Trichiurus $\mathrm{sp}$ ) di Perairan Teluk Pelabuhan Ratu, Kabupaten Sukabumi, Provinsi Jawa Barat. Departemen Manajemen Sumberdaya Perairan, Fakultas Perikanan dan Ilmu Kelautan, Institut Pertanian Bogor. Bogor.

Siregar, V. P. dan J. L. Gaol. 2012. Dampak Pemanasan Global terhadap Aktifitas Perikanan di Jawa. SEAMEO BIOTROP. Bogor.

Wijopriono. 2008. Spatial Temporal Distribution of Small Pelagic Fishes in Java Sea. Indonesian Fisheries Research Journal. 14 (1): 21-35.

Zamroni, A dan Suwarso. 2009. Perkembangan Hasil Tangkapan Ikan Pelagis Kecil di Sekitar laut Jawa. Jurnal Penelitian Perikanan Indonesia. 15(4): 307-312. 